\title{
A Perceptual Analysis of Communication and Natural Disasters Awareness across Communities in Edo North Senatorial District of Edo State
}

\author{
Obaze Abraham \\ Department of Mass Communication, Auchi Polytechnic, Auchi-Nigeria \\ Olley, Wilfred Oritsesan $(\mathrm{PhD})$ \\ Department of Mass Communication, Edo University Iyamho, Edo State - Nigeria \\ Omosotomhe, Samson. Ighiegba \\ Department of Mass Communication, Auchi Polytechnic, Auchi-Nigeria \\ Ofunne, Anthony Ubaka \\ Department of Mass Communication, Auchi Polytechnic, Auchi-Nigeria
}

\begin{abstract}
This study is designed to access communication and natural disasters awareness in Edo North Senatorial District of Edo State with emphasis on erosion and flooding issues in communities in the senatorial district. The study examined the information channels available to the people, especially on erosion and flooding control, and to know their perception towards these natural or man-made disasters. This objective of the study stems from the dangerous effects of erosion and flooding in Edo North and the perceived nonchalant attitude of the people towards their environment. Anchored on the survey method, the population of the study includes three hundred and thirty (330) residents spread across the local governments in Edo North Senatorial district of Edo State. The respondents were selected based on their residential status and without recourse to any particular demographic variable. The study recommends that even though the study found out that there is a good knowledge of what natural disaster means among the residents studied, it is important to recommend that the media in collaboration with various government agencies, especially the metrological agency to issue early warnings to residents in flood-prone areas as this will enable them to prepare ahead. It is also recommended that the mass media help in packaging messages on disaster awareness in the local dialect of the people, especially on the radio as this will help the people to understand the situations better and react where necessary. Even in print, some of the posters and handbills should be written in the local language of the people and pictures taken from their immediate environment used as a reminder to them of the reality of the danger their environment faces.
\end{abstract}

Keywords: Natural Disasters, Awareness, Erosion, Flooding, Communication

DOI: $10.7176 / \mathrm{DCS} / 10-11-02$

Publication date: November $30^{\text {th }} 2020$

\section{Introduction}

All over the world, countries are daily faced with almost an existential threat from flooding and erosion. Be it Japan, United Kingdom, United States of America, and Nigeria, the devastating effects of flooding are quite evident. (Fubara, 1987) cited in Otomofa, Okafor \& Obienusi (2015) agrees that all over the globe and also in Nigeria, widespread flooding has consistently caused catastrophic ecological havoc by destroying lives, properties, agricultural lands and social infrastructures. One thought that has troubled the minds of many people is that a considerable portion of the globe could be wiped out if nothing serious is done to arrest the situation even witness the level of destruction caused by erosion and flooding. Emeribeole (2015) chronicled some events worth mentioning, for instance, "In May 2008, floods triggered by torrential rains killed dozens of people across China, while thousands of others were victims of landslides caused by the downpours. China is not alone. In the United States of America, the Mississippi River caused damages put at several millions of dollars when it overflew its banks, flooding some cities, towns, farmlands and major industrial installations over a distance of about $250 \mathrm{~km}$ and ravaging Iowa before it heaped downstream. Apart from the Mississippi-Missouri River Systems of 1993, and that of 1995, world records of the flood have it that recently severe floods were experienced in Norway, China, Bangladesh, Ghana, The Netherlands and South Florida (p.16)."

Floods and erosion rank among the destructive natural disasters in the world today. The devastation that follows the wake of these disasters is humongous both in the number of human lives claimed and the number of properties destroyed. The horror is sometimes unimaginable and stories pathetic. The situation in Nigeria is not exactly different. Although it is important that flood may not rank as the number one claimer of human lives in the country, but it displaces more people from the communities than any other natural disaster recorded in the 
country's history. In Nigeria, though not leading in terms of claiming lives, flood effects and displaces more people than any other natural disaster with massive destruction of properties. A considerable number of the population is at risk of flooding. But what is flooding?

Otomofa et al (2015) see flooding as an environmental problem which remains an age-old phenomenon. That Flooding is a significant rise of water level in a stream, lake, reservoir or coastal system that overflows the banks. For the National Erosion and Flood Control Action Plan Committee (2005), flooding is a condition which exists when the discharge of a river or stream cannot be accommodated within the margin of its normal channels so that waters spread over adjoining land.

Macmillan (2009) defines flooding is a situation in which water from a river or rain covers large areas of land. There is an increasing vulnerability of populations and infrastructure to flooding and flood-related hazards. Although flooding is one of many hazards occurring in the human environment, its effects are significant both in terms of discomfort, destruction of lives, properties and pollution. The severity of flooding has been reckoned with, by the level of damage done (Williams, 1998).

Also, various forms and types of flooding and causes of flooding have been highlighted. Ologunorisa (2004) and Efe (2007) identified some to be natural, others man-made. They made a clear distinction between river flooding, coastal flooding and urban flooding as the major types of flooding. River flooding is simply a situation where a river bursts or overtops its banks and subsumes the areas around it. This is form is flooding is far more common than coastal flooding which takes place when heavy storms or extreme weather conditions combined with high tides cause sea levels to rise above the average normal thus forcing seawater to overflow its banks to dry land and cause coastal flooding. Urban flooding happens in usually for a short period with the capacity to cover several metres of land with water. The risk of flood is further exacerbated with the growth of urban areas coupled with harmful human activities like deforestation, obstructing the free flow of drainages, indiscriminate building without a plan and requisite approvals from town planning authorities etc. Again too, urban planning usually occurs in densely populated areas. Flooding affects both human and the environment. For instance, flooding cause soil erosion as well as sediment deposition problem downstream. With dislocation caused by coastal flooding, fish and several marine animals are often destroyed. Heavy flooding could paralyse economic activities as well as hamper vehicular movement. Bridges have been washed away by floods, as well as heavy infrastructures destroyed.

Otomofa et al (2015) summed the Nigerian experience with flooding and erosion thus: In Nigeria, some major tangible effects of flooding were recorded by Johnson (2001) for the International Committee of the Fourth International (ICFI). He reported that over 500 homes and 100 vehicles were damaged. In North-West Nigeria, up to 13 villages were destroyed in Sokoto State. More than 100 houses were destroyed by flooding from an opened barrage in neighbouring Zamfara State. Around 114 families were reportedly affected by flooding in Yobe state. In the previously serene city of Calabar in the South of Nigeria, properties worth millions of naira were destroyed by flooding in June 2001, (Johnson, 2001). In Lagos, the situation was complicated by the fact that mean sea level was higher during September and October (based on historical analysis of tidal data from 1992 - 1996).

There is no gainsaying the fact that the Nigerian environment is fraught with numerous environmental challenges which has caused so many pains to the peoples and given the government concern. However, despite the much that has been done to ameliorate the plight of the people, there still exist, much ignorance on the part of the citizenry as to how to maintain their environment to prevent environmental challenges and even what to do when disasters such as flood and erosion occur. It is in the light of the above that this study is being designed to access communication and awareness of natural disasters, with emphasis on erosion and flooding in selected communities in Edo North senatorial district of Edo State.

\section{Statement of the problem}

Flooding remains a global phenomenon which has generated immense interest from all concerned. Flooding diminishes and set villages, communities and even cities several decades behind by the massive destruction that trails it after striking. One thing is however noticeable here. Coastal regions and lower terrains suffer more in situations where flooding occurs. The causes of flooding are not only by natural processes but also by human activities. Natural processes include excessive moisture through heavy rainfall, snowmelt in the spring combined with rain while human activities refer to the way mankind alters the hydrological cycle of the river and drainage system, the altering of dams, deforestation, land reclamation, improper soil management and so forth (Doocy, Daniels, Murray and Kirsch, 2013).

The negative impact of flooding in several communities in Nigeria especially as it affects farmers with these farmers experiencing low crop yields thus further impoverishing them. In several communities across Edo 
North like Agenegbode, Udaba Ekperi, Anegbette, Ofukpo, Agbadu etc. over 5,000 persons were displaced by floods, over twenty communities around the bank of River Niger were submerged by the ravaging water, leaving properties like farmlands, buildings and other household items worth several billions of naira destroyed. The floods also hampered farming and fishing activities which remain the main occupation of the people of this region.

The growing increase in population, human activities, coupled with flooding in the Edo North have increased the need to evaluate the impacts of flooding on socio-economic activities in Edo North community. What measures can be put in place to create awareness? Experts agree that man-made flooding can be reduced drastically if activities leading to it can be put in check. As such, this study set out to examine the issues surrounding a lack of proper dissemination of messages through media campaigns to address the issue of flooding. What infrastructural developments are needed to address issues of flooding in Edo north communities?

\section{Objectives of the study}

1. To assess the level of knowledge of the residents of Edo North Senatorial District towards the occurrence of natural disasters such as erosion and flooding.

2. To measure the effectiveness of communication messages on Erosion and Flooding, packaged for the awareness of enlightenment of the people of Edo North Senatorial District.

3. To examine the level of natural disaster information awareness among the people of Edo North Senatorial District.

4. To ascertain the challenges militating against the understanding of communication messages and information packaged to create awareness of information for the people of Edo North Senatorial District.

\section{Research Questions}

1. What is the level of knowledge of the residents of Edo North Senatorial District towards the occurrence of natural disasters such as erosion and flooding?

2. How can the communication messages on Erosion and Flooding, be effectively packaged for the awareness of enlightenment of the people of Edo North Senatorial District?

3. What is the level of natural disaster information awareness among the people of Edo North Senatorial District?

4. What are the challenges militating against the understanding of communication messages and information packaged to create awareness of information for the people of Edo North Senatorial District?

\section{Theoretical Perspective}

This study is anchored on the Perception/Reception theory. Perception has been defined as 'the process by which we utilize external sensory information in combination with other internal conscious and unconscious workings of the brain to make sense of the world' (Barry, 2002). This is specifically the hunting ground of media/communication theorists; and the contact point of the cognitive dissonance theory, the selective exposure theory as well as the reception theory.

According to Klapper (1960), Mass Communication, as a mediator in persuasive communication, does not influence the individual directly but it does reinforce the individual's predisposition - and the five mediating factors here are:

- Predispositions and the related processes of selective exposure, perception, and retention.

- The groups, group norms, to which the audience members belong.

- Dissemination of the content of communication interpersonally.

- The exercise of opinion leadership.

- $\quad$ The nature of mass media in a free enterprise society (Klapper, 1960).

These mediating factors directly or indirectly relate to the context of the media/mass communication and it is here that the relationship between perception and reception theories exists.

Three names are recurrent in the abundant literature on reception theories:

1. Hans-Robert Jauss (1982) developed the theory for the interrogation of the literary text.

2. Stuart Hall (1982) who applied it to media and communication studies; and

3. Sussan Bennett (1990) who carried the discourse into theatre/performance.

Reception theories interface the text/performance with the reader/audience, and meaning is seen as residing less in the text and more in the context: it is from the context that the reader/audience negotiates the meaning of the text/performance. Context, in this regard, is seen primarily as a function of:

1. the individual's cultural background

2. the individual's life experiences

3. the individual's preconceived notions of the text/performance

4. the circumstances of exhibition/performance; and opinion leadership. 


\section{Methodology}

The research design used for this study was the survey. The survey research design is considered appropriate for this study because the population of this study is a large one and survey method will help in choosing a sample which is representative of the entire population of the study. The method allows the collection of a large amount of data from a sizeable population in a highly economical way (Saunders et al, 2003, p.92). The method is more convenient and cost-effective. The instrument for the collection of data for this study was a well-structured questionnaire.

The convenient sampling technique was used to select a representative sample of respondents for this study. The researchers conveniently selected persons and professionals who are knowledgeable in disaster management, environment and environmental communication to get their opinion on the subject of the study.

For this study, the population includes three hundred and thirty (330) residents spread across the local governments in Edo North Senatorial district of Edo State. The respondents were selected based on their residential status and without recourse to any particular demographic variable.

\section{Data presentation and analysis}

A total of 330 residents were sampled in five local government areas that make up Edo North Senatorial District of Edo State. Out of the 330 copies of the questionnaire that were administered, 314 were retrieved, while 308 respondents following their "yes" response to item 3 formed the final sample size. Item 3 (Are you aware of the issues of a natural disaster such as erosion and flooding in Edo North?) was specifically included to screen out respondents who said "No".

With the 308 respondents that took part in the study, the response rate stood at $93 \%$. There were 246 males $(79.87 \%)$ and 62 females $(20.13 \%)$. Details of the survey data collected were tabulated and computed in percentages.

Table 1: Familiarity with the occurrence of a natural disaster such as flooding and erosion in Edo North

\begin{tabular}{|c|c|c|}
\hline Option & Frequency & Percentage \\
\hline I know a lot & 187 & 61 \\
\hline I am fairly familiar & 112 & 36 \\
\hline I don't know much & 9 & 3 \\
\hline Never heard of such occurrences & 0 & 0 \\
\hline Total & 308 & $100 \%$ \\
\hline
\end{tabular}

Information was sought on respondents' familiarity with the occurrences of natural disasters such as flooding, erosion etc. in Edo North. A substantial number of respondents -187 (61\%) indicated that they have considerable knowledge of these occurrences around the area of study. There is another category that says they have a fair insight into these disasters and represent $36 \%$ of the sample population. What can be deduced from this is that awareness is abundant as it concerns being conscious of what a natural disaster is and more specifically, the recent incidences of flooding and erosion in Edo North. Only a very small percentage (3\%) which translates to 9 respondents seem not to know much about these disasters. From the data gathered in table 1 , we can conclude with some level of certainty that there is a high level of awareness as regarding the existence and occurrences of disasters like flooding and erosion. This is possibly the reason why no one indicated not to have ever heard about incidences of flooding and erosion in Edo North.

Table 2: Knowledge of community being prone to the occurrence of these disasters

\begin{tabular}{|c|c|c|}
\hline Option & Frequency & Percentage \\
\hline Yes & 299 & 97 \\
\hline No & 0 & 0 \\
\hline Not Sure & 9 & 3 \\
\hline Total & 308 & $100 \%$ \\
\hline
\end{tabular}

In Edo North, certain communities are prone to incidences of natural disasters such as flooding and erosion for several reasons. These reasons will include the communities sharing common boundaries with coastlines like River Niger etc. which sometimes overflow its banks. Communities like Agenegbode in Etsako East and Anegbete in Etsako Central readily fit into this category. Other communities such as Auchi experience flooding and erosion due to its topography and lack of proper drainage networks. As such, responses were sought from respondents as to the level of knowledge whether they know the specific communities and localities prone to these natural disasters like flooding and erosion. An overwhelming percentage (97\%) answered in the affirmative. This means that majority of the sampled population know the communities that are likely to experience flooding and erosion. This is a welcome development as preventive measures and early warning signs of imminent disaster can easily be disseminated to such communities having known these communities being prone to experience flooding. Only nine respondents which represent $3 \%$ of the population indicated that they are not so sure of the communities where these natural disasters are likely to occur. 
Table 3: Opinion on who should be responsible for creating disaster awareness messages

\begin{tabular}{lcc}
\hline \multicolumn{1}{c}{ Option } & Frequency & Percentage \\
\hline Flood Management Experts & 97 & 31 \\
Disaster Management Agencies & 114 & 37 \\
Community Unions and associations & 61 & 20 \\
Corporate Organisation and NGOs & 36 & 12 \\
\hline \multicolumn{1}{c}{ Total } & $\mathbf{3 0 8}$ & $\mathbf{1 0 0 \%}$ \\
\hline
\end{tabular}

A very controversial issue has been the nagging question of whose responsibility it is to disseminate information about natural disasters such as flooding and erosion. When this question was put across to respondents, the responses were quite divergent. 144 (37\%) respondents put this responsibility squarely at the doorsteps of Disaster Management Agencies like National and State Emergency Management Agencies (NEMA and SEMA). The reason for this cannot be far from the fact that these agencies are statutorily saddled with the responsibility of managing all disaster cases across Nigeria both at the federal and state levels. These agencies are far more equipped and possibly have the financial wherewithal to address disaster issues in comparison to other players. Another set of respondents however differ in their submission in respect who should be responsible for creating awareness about disaster issues. Table 3 shows that 97 (31\%) respondents believe that flood management experts should shoulder this responsibility. The reason for this could be the level of expertise they could bring to bear in the design and dissemination of such messages being experts with specialised knowledge.

Another set of respondents believe that community unions and associations should be responsible for creating awareness about natural disasters such as flooding and erosion. These unions and associations are closer to the people as they have direct contact with the affected communities. In addition to this, they are based in these communities. This is possibly the reason why 61 respondents amounting to $20 \%$ of the sample population believe they should be in a better position to create awareness about looming disasters. As part of some corporate organisation's social responsibility, helping their host communities in any form can be considered a key intervention. To this end, $36(12 \%)$ of the respondents placed the responsibility of creating awareness about natural disasters such as flooding and erosion at the doorsteps of corporate organisations and NGOs.

Table 4: Personal experience of any natural disaster in a community such as flooding and erosion.

\begin{tabular}{|c|c|c|}
\hline Option & Frequency & Percentage \\
\hline Yes & 276 & 90 \\
\hline No & 19 & 6 \\
\hline Not Sure & 13 & 4 \\
\hline Total & 308 & $100 \%$ \\
\hline
\end{tabular}

On individual experience regarding occurrences of flooding or erosion in their immediate communities, the majority of the sampled communities or individual have encountered flooding or erosion in one form or the other. In total, 90\% (276) of the respondents answered in the affirmative to have been directly affected by natural disasters such as flooding and erosion. This implies that the sampled areas around Edo North are prone to occurrences of flooding and erosion. Also, 19 respondents responded with no having not experienced any form of flooding in their areas. This, however, points to the fact that erosion and flooding are not experienced in every part of Edo North. In the minority are those who are not so sure. They constitute $4 \%$ (13 respondents).

Table 5: Channels of communication respondents are exposed to in their community for accessing information

\begin{tabular}{lccc}
\hline & Option & Frequency & Percentage \\
\hline Word of mouth/opinion leaders & 59 & 19 \\
Television & 75 & 24 \\
Radio & 152 & 50 \\
Newspapers & & 22 & 7 \\
\hline \multicolumn{2}{c}{ Total } & $\mathbf{3 0 8}$ & $\mathbf{1 0 0 \%}$ \\
\hline
\end{tabular}

The study sought to know the various channels of communication available to the respondents as avenues of accessing information. This is important because of the peculiarity of each community. Their access to information varies. From the data gathered, radio remains the most popular medium for accessing information among residents of Edo North. Precisely half of the population (50\%) which amounts to 152 respondents get a considerable load of information from Radio. What we can deduce from this is the fact that radio has the highest level of penetration in rural communities as shown clearly from the above table. Closely the following radio as a major channel of information is television. The decentralisation of Nigerian Television Authority (NTA) and African Independent Television (AIT) operations saw the establishment of several network stations across Nigeria such as NTA Uzairue, AIT Agenegbode etc. This has made access to information through television possible in these communities with 75 respondents $(24 \%)$ using it as a channel getting information. However, in some communities, word of mouth /opinion leaders remains the major channels for accessing information primarily due to level of exposure, norms and values of such communities where the village square remains a 
major point of information dissemination. Still, some get information through newspapers. These group of respondents are the literate ones who are in the minority.

Table 6: Awareness of message disseminated by these channels on disaster awareness such as erosion and flooding in recent times.

\begin{tabular}{|c|c|c|}
\hline Option & Frequency & Percentage \\
\hline Yes & 299 & 97 \\
\hline No & 0 & 0 \\
\hline Not Sure & 9 & 3 \\
\hline Total & 308 & $100 \%$ \\
\hline
\end{tabular}

It is one thing to access information but a different thing altogether when it comes to accessing the information on natural disasters such as erosion and flooding from these channels. The study, therefore, sought to find out the degree to which these channels make available information on flooding and erosion in Edo North and whether the respondents are aware of these messages. The majority - 299 respondents which represent $97 \%$ of the sampled population answered in the affirmative that they are aware of these channels disseminating messages on natural disasters such as flooding and erosion. Only 3\% (9 respondents) were not so sure of accessing the information on flooding and erosion through these channels. We can conclude from the above that indeed, a sizeable number of the population resident in Edo North do get information on natural disasters from a variety of channels as discussed earlier.

Table 7: Effectiveness and efficiency of the messages creating awareness about erosion and flooding

\begin{tabular}{|c|c|c|}
\hline Option & Frequency & Percentage \\
\hline Very Effective & 96 & 31 \\
\hline Effective & 101 & 33 \\
\hline Fair & 62 & 20 \\
\hline Not Effective & 49 & 16 \\
\hline Total & 308 & $100 \%$ \\
\hline
\end{tabular}

In addition to the population accessing information about natural disasters such as flooding and erosion from the channels enumerated earlier, the study further sought to know the extent to which these messages were effective in creating awareness about erosion and flooding in the entire Edo North. This is pertinent against the backdrop of the frequency with which these disasters occur. A considerable number 101 (33\%) adjudge the messages on natural disasters from these channels to be effective. In other words, these messages have become quite useful to the residents of the communities being studied. This is possibly responsible for another 96 respondents (31\%) believe these messages are very efficient. While 20\% (62 respondents) of the population consider the messages to be fair in their ranking of the effectiveness of the content of what is being disseminated on natural disasters. There is however a fourth group that rank the effectiveness of these messages low. They believe that the messages are ineffective and make little or no impact on the communities and individuals. They are however in the minority - 49 in total representing $16 \%$ of the sampled population.

Table 8: Awareness of any information on imminent flooding before the recent disaster.

\begin{tabular}{|c|c|c|}
\hline Option & Frequency & Percentage \\
\hline Yes & 244 & 79 \\
\hline No & 13 & 4 \\
\hline Not Sure & 51 & 17 \\
\hline Total & 308 & $100 \%$ \\
\hline
\end{tabular}

Earlier warning signs remain the goal of any campaign aimed at creating awareness about imminent natural disasters such as flooding and erosion. In the run-up the recent flooding that ravaged riverine communities across Edo North, a considerable number of media organisations, as well as non-conventional channels as enumerated earlier, did make concerted efforts to create awareness about the impending danger. They re-echoed messages from the Nigerian Meteorological Agency, National and State Emergency Management Agencies, NGOs etc. who warned the affected communities to evacuate their homes to forestall any casualty. As a result of this, the sought to determine to what extent this awareness was created before the recent flooding in 2018 in these communities. $79 \%$ which is a total of 244 respondents confirmed to have received some form of information about the looming danger of an impending flood/erosion from the available channels. 51 respondents $(17 \%)$ were so sure whether they got these messages before the flooding. While only $13(4 \%)$ respondents clearly in the minority claimed not to have seen or heard any message about the recent flooding in 2018 . 
Table 9: Sources of information on disasters

\begin{tabular}{lccc}
\hline & Option & Frequency & Percentage \\
\hline Social Media & 49 & 16 \\
Government Agencies & 20 & 6 \\
Mass Media & 201 & 65 \\
Opinion Leaders & 29 & 9 \\
Others & 0 & 0 \\
\hline \multicolumn{2}{c}{ Total } & $\mathbf{3 0 8}$ & $\mathbf{1 0 0 \%}$ \\
\hline
\end{tabular}

On the channels available as sources of information on natural disasters such as flooding and erosion to the communities being studied, the conventional media (television, radio, newspapers) led with 201 respondents representing $65 \%$ saying they get the bulk of the news about erosion and flooding from the mass media. This we can easily attribute to the level of penetration of some of these media. Radio for instance is quite popular among rural communities. So is television especially with the establishment of local television stations by NTA and AIT in and around Edo North who have segments where they broadcast in local dialects thus extending their reach? There are also community newspapers and magazines such as Afenmai Voice etc. with considerable penetration.

Closely following the mass media as channels of information is the now ever-growing social media. Most social media sites are replete with news from major news providers as well as a myriad of other agencies. As such, they have become a major source of accessing information, especially to the then younger generation. A total of 49 respondents (16\%) from the data gathered now access information on natural disasters in these communities from social media. This is partly due to the penetration of mobile technology in most communities in Edo North with a sizeable number of persons owning a mobile phone thus giving them unfettered access to the internet and by extension - social media. Also, the place of opinion leaders in these communities remains intact when it comes to sourcing information. 29 respondents $(9 \%)$ from the above still rely heavily on opinion leaders within the community to get any information concerning disasters like flooding. Another $6 \%$ totalling 20 respondents rely on government agencies to access information on disasters in their communities.

Table 10: Language for communicating the information on flooding and erosion

\begin{tabular}{lccc}
\hline & Option & Frequency & Percentage \\
\hline English & 167 & 54 \\
Local Language & 43 & 14 \\
Pidgin & 98 & 32 \\
\hline \multicolumn{2}{c}{ Total } & $\mathbf{3 0 8}$ & $\mathbf{1 0 0 \%}$ \\
\hline
\end{tabular}

On the language used in communicating the information about flooding and erosion, the majority of it is in English. 167 (54\%) respondents got messages about flooding and erosion in English mostly from the mass media/social media. However, to reach more people with messages on flooding and erosion, a sizeable percentage $(32 \%)$ of the respondents 98 in total got the messages delivered to them in pidgin which is quite popular and widely spoken around Edo north and the entire state in general. Jingles, public service announcement are oftentimes rendered in pidgin. To cover the entire population, some of the channels including the mass media such as radio and television do translate these massages to local languages like Uzairue, Weppa, Okpella, Uneme, etc. In line with this, 43 respondents which are $14 \%$ of the sampled population received messages bothering on flooding and erosion in their local language or dialect.

Table 11: Understanding of the communicated information on flooding and erosion

\begin{tabular}{|c|c|c|}
\hline Option & Frequency & Percentage \\
\hline Yes & 239 & 77 \\
\hline No & 51 & 17 \\
\hline Not Sure & 18 & 6 \\
\hline Total & 308 & $100 \%$ \\
\hline
\end{tabular}

Every disseminated message is intended to pass a message across to the recipient. This is because a message can be misunderstood as a result of intervening variables such as selective attention, selective retention etc. this end, the research sought to know whether or not the respondents understood the messages they got through the various channels. $77 \%$ (239 respondents) affirmed to understand the messages on flooding and erosion. In other words, the messages were able to create the level of awareness that is required considering the devastation that comes with flooding and erosion. 51 respondents $(17 \%)$ said no indicating that they did not understand the messages they received. While 18 respondents (a small percentage - 6\%) were not sure if they understood or not any of the messages on they got through the numerous channels. 
Table 12: Opinion on if the communicated information on flooding and erosion required an interpreter to understand.

\begin{tabular}{lccc}
\hline & Option & Frequency & Percentage \\
\hline Yes & & 91 & 29 \\
No & & 184 & 60 \\
Not Sure & Total & 33 & 11 \\
\hline & & $\mathbf{3 0 8}$ & $\mathbf{1 0 0 \%}$ \\
\hline
\end{tabular}

Information on flooding can sometimes contain technical or scientific terms that will require further explanation for one to understand. Instances also could abound where the messages on flooding and erosion are rendered in a language such as English that the less educated will find difficult to understand. Form findings in the field, the majority - $184-60 \%$ said they did not need an interpreter to understand the messages. they clearly understood the message. The reason for this will range from translating these messages to local ones, the use of pidgin etc. thus bringing the message closer to the people and speaking a language they can easily identify with. However, 91 respondents differ. This group represents $29 \%$ of the total sampled population. In their response, answered in the affirmative that they did not understand the message and thus required more explanation to fully the import of what was communicated. This we can likely attribute to level of education and possibly in areas where the message was not translated or interpreted in local languages. Finally, 11\% (the minority of 33) of the respondents were not sure whether they needed the message interpreted to them or not.

Table 13: Opinion on if the messages or earlier warnings about imminent flooding were obeyed

\begin{tabular}{lccc}
\hline & Option & Frequency & Percentage \\
\hline Yes & & 227 & 74 \\
No & & 13 & 4 \\
Not Sure & Total & 68 & 22 \\
\hline & & $\mathbf{3 0 8}$ & $\mathbf{1 0 0 \%}$ \\
\hline
\end{tabular}

Before recent incidences of flooding and erosion, a considerable amount of information disseminated to the communities under study was centred around the imminent danger that awaits them if certain steps were not taken to either avert the imminent danger. Better environmental practices were canvassed by these messages, such a blockade of waterways, indiscriminate dumping of refuse into drainages and constructions of buildings in waterlogged areas etc. The study, therefore, sought to know whether these warnings were obeyed. Majority of respondents $(227-74 \%)$ said that these warnings were obeyed. This we can say is partly responsible for the zero records in terms of loss of lives in recent incidences of flooding and erosion in communities in Edo North as inhabitants of these communities yielded to the warnings contained in these messages. Only $4 \%$ which amounts 13 respondents failed to obey these warnings. While 68 respondents $(22 \%)$ were so sure whether these warnings were obeyed.

Table 14: Satisfaction with the messages received before the flooding

\begin{tabular}{|c|c|c|}
\hline Option & Frequency & Percentage \\
\hline Yes & 250 & 81 \\
\hline No & 41 & 13 \\
\hline Not Sure & 17 & 6 \\
\hline Total & 308 & $100 \%$ \\
\hline
\end{tabular}

In the event of natural disasters such as flooding and erosion occurring, blames are often apportioned to certain agencies and persons saddled with the responsibility of bringing awareness to the affected communities specifically where warnings were not sufficiently made available them. To this end, the study, therefore, sought to find out whether the communities studied in Edo North were satisfied with the amount and quality of information they received before the flooding from the various channels enumerated earlier. Again, from findings, the majority were satisfied with the information they got adjudging same to be effective in that precautionary measures were triggered by such early warnings and messages. Precisely, 250 (81\%) respondents said they were satisfied with the amount of information made available to them concerning the then looming danger of imminent flooding and erosion. On the other hand, 41 respondents $(13 \%)$ however differed in that the information made available before the flooding was not satisfactory in their estimation. This leaves room for some adjustment and improvement going forward in crafting messages for the consumption of this flood-prone communities. 6 respondents were however not sure of the efficacy of the messages they received. They represent the minority though at $6 \%$. They could not be categorical whether they were satisfied with what they received concerning the imminent flooding and erosion. 
Table 15: Going back to the damaged homes when the flooding recedes?

\begin{tabular}{|c|c|c|}
\hline Option & Frequency & Percentage \\
\hline Yes & 155 & 50 \\
\hline No & 66 & 21 \\
\hline Not Sure & 87 & 28 \\
\hline Total & 308 & $100 \%$ \\
\hline
\end{tabular}

The study further sought to find out whether despite the recent flooding residents of the communities studied are still ready to go back to their damaged homes after the floods receded. This is not unconnected with the values and traditions of the people in these communities who consider these communities as their ancestral lands and heritage with no intention of relinquishing their ancestral homes to flood or erosion. Exactly half $(50 \%)$ of the respondents - 155 answered in the affirmative that they are going back to their homes when the flood recedes giving credence to the above assertion. $28 \%$ (87) were so sure if they want to go back to their damaged homes to begin rebuilding having witnessed such devastation from the floods and lost all they have with possibly no guarantees that the floods will not return in no distant future. However, 66 respondents representing $21 \%$ of the sampled population did not hesitate as the declared their intention not to return to their damaged homes.

\section{Discussion of Findings}

Research Question 1: What is the level of knowledge of the residents of Edo North Senatorial District towards the occurrence of natural disasters such as erosion and flooding?

On the above research question, the study discovered that the residents of Edo North Senatorial District have a good knowledge of what natural disaster means. On information sought on the respondents' familiarity with the occurrences of natural disasters such as flooding, erosion etc. in Edo North, a substantial number of respondents indicated that they have considerable knowledge of these occurrences around the area of study. Based on this, the study can conclude with some level of certainty that there is a high level of awareness as regarding the existence and occurrences of disasters like flooding and erosion.

Again, in Edo North, many communities are prone to incidences of natural disasters such as flooding and erosion for several reasons and they will include the communities sharing common boundaries with coastlines like River Niger etc. which sometimes overflow its banks in places such as Agenegbode in Etsako East and Anegbete, Ekperi Udaba and others in Etsako Central. In the same vein, Auchi in Etsako West experience flooding and erosion due to its topography and lack of proper drainage networks. These are issues that occur regularly and may have contributed to the level of awareness among the residents. Another implication of this is that the majority of the residents already know or have an idea of the communities that are likely to experience flooding and erosion when the rainy seasons approach. This is a welcome development as preventive measures and early warning signs of imminent disaster can easily be disseminated to such communities having known these communities being prone to experience flooding.

Research Question 2: How are the communication messages on erosion and flooding, packaged for the awareness or enlightenment of the people of Edo North Senatorial district?

On how are the communication messages on erosion and flooding, packaged for the awareness or enlightenment of the people of Edo North Senatorial district, the study sought to know the various channels of communication available to the respondents as avenues of accessing information. This became important because of the peculiarity of each community in the district and the fact that their access to information varies. The study reveals that radio remains the most popular medium for accessing information among residents of Edo North. What can be deduced from this is the fact that radio has the highest level of penetration in rural communities in Africa. Although television is still a preferred medium in the area owing to the decentralisation of Nigerian Television Authority (NTA) and African Independent Television (AIT) operations which saw the establishment of community centres such as NTA Uzairue and AIT Agenegbode. This has made access to information through television possible in these communities. However, in some communities, word of mouth /opinion leaders remains the major channels for accessing information primarily due to level of exposure, norms and values of such communities where the village square remains a major point of information dissemination. All these were the channels through which communication messages on erosion and flooding, packaged for the awareness or enlightenment of the people of Edo North Senatorial district.

It is one thing to access information but a different thing altogether when it comes to accessing the information on natural disasters such as erosion and flooding from these channels. The study, therefore, sought to find out the degree to which these channels make available information on flooding and erosion in Edo North and whether the respondents are aware of these messages. The study shows that a sizeable number of the population resident in Edo North do get information on natural disasters from a variety of channels as discussed earlier.

In addition to the population accessing information about natural disasters such as flooding and erosion from the channels enumerated earlier, the study further sought to know the extent to which these messages were 
effective in creating awareness about erosion and flooding in the entire Edo North. This is pertinent against the backdrop of the frequency with which these disasters occur. The study discovered that a considerable number adjudged the messages on natural disasters from these channels to be effective. In other words, these messages have become quite useful to the residents of the communities being studied.

Research Question 3: What is the level of natural disaster information awareness among the people of Edo North Senatorial District?

Earlier warning signs remain the goal of any campaign aimed at creating awareness about imminent natural disasters such as flooding and erosion. In the run-up the recent flooding that ravaged riverine communities across Edo North, a considerable number of media organisations, as well as non-conventional channels as enumerated earlier, did make concerted efforts to create awareness about the impeding danger. They re-echoed messages from the Nigerian Meteorological Agency, National and State Emergency Management Agencies, NGOs etc. who warned the affected communities to evacuate their homes in order to forestall any casualty. As a result of this, the sought to determine to what extent this awareness was created prior to the recent flooding in 2018 in these communities. The majority of the respondents confirmed that they did receive some form of information about the looming danger of an impending flood/erosion from the available channels. The implication of this is that the mass media are still effective in the dissemination of information on natural disasters in the country. Obviously, most of the information and awareness at the disposal of the general public were created or disseminated by different organisations and individuals using available media channels.

Research Question 4: What is the residents' opinion of the communicated messages and information packaged to create awareness of information for the people of Edo North Senatorial District?

Prior to recent incidences of flooding and erosion, a considerable amount of information disseminated to the communities under study were centred around the imminent danger that awaits them if certain steps were not taken to either avert the imminent danger. Better environmental practices were canvassed by these messages, such a blockade of waterways, indiscriminate dumping of refuse into drainages and constructions of buildings in waterlogged areas etc. The study, therefore, concludes that can say is partly responsible for the zero records in terms of loss of lives in recent incidences of flooding and erosion in communities in Edo North as inhabitants of these communities yielded to the warnings contained in these messages.

Again, in the event of natural disasters such as flooding and erosion occurring, blames are often apportioned to certain agencies and persons saddled with the responsibility of bringing awareness to the affected communities specifically where warnings were not sufficiently made available them. To this end, the study, therefore, sought to know whether the inhabitants were satisfied with the amount and quality of information they received before the flooding from the various channels enumerated earlier. Again, from findings, the majority were satisfied with the information they got adjudging same to be effective in that precautionary measures were triggered by such early warnings and messages.

\section{Conclusion}

The need for awareness creation in times of disaster has become a sine qua non. There is no gainsaying the fact that the Nigerian environment is fraught with numerous environmental challenges which have caused so many pains to the people, either in the rural of the urban areas and this has also given various governments much concern. But despite the obvious efforts both at the local, state and the federal levels to ameliorate the plight of the people, there still exist, much ignorance on the part of the citizenry, owing to poor communication of disaster messages. It was in this light that this study was designed to access communication and awareness of natural disasters, with emphasis on erosion and flooding in selected communities in Edo North senatorial district of Edo State.

The study concludes disaster awareness amongst the people in the studied area is high as this was attested to by the majority of the residents who indicated that they already know or have an idea of the communities that are likely to experience flooding and erosion when the rainy seasons approach. This no doubt is a welcome development as preventive measures and early warning signs of imminent disaster can easily be disseminated to such communities having known these communities being prone to experience flooding. The study also concluded that since radio remains the most popular medium for accessing information among residents of Edo North, as the highest level of penetration in rural communities is very high and the followership or listenership base is encouraging, this has also encouraged the propagation of messages to the people and has also made access to information possible in these communities.

\section{Recommendations}

1. even though the study found out that there is a good knowledge of what natural disaster means among the residents studied, it is important to recommend that the media in collaboration with various government agencies, especially the metrological agency to issue early warnings to residents in floodprone areas as this will enable them to prepare ahead. 
2. It is also recommended that the mass media help in packaging messages on disaster awareness in the local dialect of the people, especially on the radio as this will help the people to understand the situations better and react where necessary. Even in print, some of the posters and handbills should be written in the local language of the people and pictures taken from their immediate environment used as a reminder to them of the reality of the danger their environment faces.

3. Aside from the information on disaster awareness in the areas affected, the mass media and the various government agencies must carry out educational projects that will properly educate the rural dwellers on how to take care of their environments and avoid issues of erosion especially.

4. The mass media and the various agencies saddled with the responsibility of managing the environment or providing succour for victims of environmental disasters should continue to improve on the amount and quality of information they received by the rural dwellers before any occurrence of the disaster.

\section{References}

Doocy, S.; Daniels, A.; Murray, S. and Kirsch, T.D. (2013). The Human Impact of Floods: a Historical Review of Events 1980-2009 and Systematic Literature Review. Available at http://currents.plos.org/disasters/article/thehuman-impact-of-floods-a-historical-review-of-events-19802009-and -systematic-literature-review/. Accessed: 10/03/2016.

Efe, S.I. (2007). Urban Flooding in Abraka, Delta State, Nigeria. In Journal of Environmental Conservation and Research 1(1): 96-103.

Emeribeole C.A., (2015) Managing Flood Disasters in Nigerian Cities: Issues and Strategies towards Meeting the Challenges in the Modern World. (A Case Study of Owerri Metropolis Imo state Nigeria). Sofia, Bulgaria: FIG Working Week 2015, 17-21 May 2015.

Macmillan (2009). Flooding-definition of flooding by Macmillan Dictionary. Available at http://www.macmillandictionary.com/dictionary/british/flooding. Accessed 12/03/2016

National Erosion and Flood Control Action Plan Committee (2005). The Federal Government Official Gazette, Abuja.

Ologunorisa, T. E. (2004). An Assessment of Flood Vulnerability Zones in the Niger Delta, Nigeria. In. International Journal of Environment Studies. 61(1):31-38.

Otomofa, J. O.; Okafor, B. N. \& Obienusi, E. A. (2015). Evaluation of the Impacts of Flooding On SocioEconomic Activities in Oleh, Isoko South Local Government Area, Delta State. In Journal of Environment and Earth Science. Vol.5, No.18, 2015.

Williams, L. (1998). The effect of wildfire or runoff and erosion in native Eucalyptus Forest. In Journal of Hydrological Processes. 12 (4): 251-268. 